\title{
Effects of $\gamma$-hexachlorocyclohexane and L-3,3',5- triiodothyronine on rat liver cytochrome P4502E1- dependent activity and content in relation to microsomal superoxide radical generation
}

\author{
VIRGINIA FERNÁNDEZ ${ }^{1}$, LAURA MASSA ${ }^{1}$, LUIS QUIÑONES ${ }^{1}$, KARIN A SIMON- \\ GIAVAROTTI $^{2}$, LEANDRO GIAVAROTTI ${ }^{2}$, VÂNIA D'ALMEIDA ${ }^{3}$, LIGIA A AZZALIS ${ }^{2}$, \\ VIRGINIA BC JUNQUEIRA ${ }^{4}$ and LUIS A VIDELA ${ }^{1}$.
}

1Programa de Farmacología Molecular y Clínica, Instituto de Ciencias Biomédicas, Facultad de
Medicina, Universidad de Chile, Casilla 70000, Santiago-7, Chile
${ }^{2}$ Departamento de Bioquímica, Instituto de Química, Universidade de São Paulo, São Paulo, Brasil
${ }^{3}$ Centro de Genética Médica, UNIFESP, São Paulo, Brasil
${ }^{4}$ Disciplina de Geriatría, Departamento de Medicina, UNIFESP, São Paulo, Brasil

\begin{abstract}
Liver microsomal cytochrome P4502E1-dependent p-nitrophenol (PNP) hydroxylation and expression of cytochrome P4502E1 were studied in rats subjected to $\gamma$-hexachlorocyclohexane $(\mathrm{HCCH})$ or L-3,3, 5triiodothyronine $\left(\mathrm{T}_{3}\right)$ administration as a possible mechanism contributing to superoxide radical $\left(\mathrm{O}_{2}{ }^{-}\right)$generation. $\mathrm{HCCH}$ treatment (a single dose of $40 \mathrm{mg} / \mathrm{kg}$ body wt) produced a $43 \%$ increase in the content of total cytochrome $\mathrm{P} 450$, whereas $\mathrm{T}_{3}$ (daily doses of $0.1 \mathrm{mg} / \mathrm{kg}$ body wt for two consecutive days) led to a $37 \%$ decrease. NADPHdependent $\mathrm{O}_{3}-$ generation was elevated by $\mathrm{HCCH}$ and $\mathrm{T}_{3}$, expressed as either per mg of protein or per nmol of cytochrome $\mathrm{P} 450$, with a $135 \%$ enhancement in the $\mathrm{O}_{2}^{-}$production/superoxide dismutase (SOD) activity ratios being observed in both conditions. This was partly due to depression of SOD activity. Concomitantly, the molecular activity of NADPH-cytochrome p450 reductase was enhanced by 90 and $69 \%$ by $\mathrm{HCCH}_{\text {and }}$, respectively. In these conditions, microsomal PNP hydroxylation showed increases of 58 and $45 \%$ in $\mathrm{HCCH}-$ and $\mathrm{T}_{3}$-treated rats over control values, respectively, with a parallel $31 \%(\mathrm{HCCH})$ and $41 \%\left(\mathrm{~T}_{3}\right)$ enhancement in the content of cytochrome P4502E1 assessed by western immunoblotting. We conclude that $\mathrm{HCCH}$ and $\mathrm{T}_{3}$ enhance the expression and activity of cytochrome $\mathrm{P} 4502 \mathrm{E} 1$ and that of NADPH-cytochrome $\mathrm{P} 450$ reductase in rat liver, regardless of the changes in total cytochrome P450 content, representing major contributory mechanisms to microsomal NADPH-dependent $\mathrm{O}_{2}^{--}$generation.
\end{abstract}

Key terms: $\gamma$-Hexachlorocyclohexane; L-3,3',5-Triiodothyronine; Superoxide radical; Cytochrome P4502E1; Rat liver

\section{INTRODUCTION}

Reactive species derived from chemicals, oxygen, or nitrogen have been implicated as putative noxious intermediates responsible for cellular damage (Comporti, 1989; Radi et al., 1991). Because electrophilic metabolites or radicals and excited species can readily interact with essential biomolecules, covalent binding to cellular components and/or their oxidative modification can occur, leading to structural and functional alterations when protective mechanisms are overcome or exhausted (Comporti, 1989; Kappus, 1987). Previous work by our group has shown that acute $\gamma$-hexachlorocyclohexane (HCCH or lindane) treatment enhances the oxidative stress status of the liver, an effect that is both dose- (Junqueira et al., 1986) and time-dependent (Junqueira et al., 1988; Barros et al., 1988) and that seems to be primarily related to its biotransformation by the microsomal P450 system. The reductive activity of this pathway generates electrophilic intermediates of $\mathrm{HCCH}$ (Baker 
et al., 1985) which are conjugated with glutathione (GSH) for elimination as mercapturates (Kurihara et al., 1979), thus inducing an early (4-6 h) phase of oxidative stress involving GSH depletion (Barros et al., 1988) with a lipid peroxidative response (Junqueira et al., 1988). Induction of cytochrome $\mathrm{P} 450$ at later times after $\mathrm{HCCH}$ intoxication $(24 \mathrm{~h})$ further enhances the oxidative stress status of the liver due to acceleration of xenobiotic biotransformation (Videla et al., 1990) and higher microsomal NADPH-dependent superoxide radical $\left(\mathrm{O}_{2}{ }^{--}\right)$ generation (Junqueira et al., 1988), with higher oxidation index (Fernández et al., 1999). Furthermore, the time course of the changes in parameters related to oxidative stress induced by $\mathrm{HCCH}$ coincides with the onset and progression of morphological lesions in the liver, which return to normal depending on the hepatic content of the insecticide and on the extent of microsomal production of $\mathrm{O}_{2}{ }^{--}$(Junqueira et al., 1988; 1997).

From the toxicological point of view, cytochrome P4502E1, the ethanol-inducible form (Lieber, 1997), is considered of particular interest due to (a) its capacity to oxidize several chemicals (i.e., ethanol, carbon tetrachloride, acetaminophen, nitrosamines) to reactive intermediates that are hepatotoxic (Guengerich et al., 1991; Koop, 1992; Lieber, 1997), and (b) its poor coupling with NADPH-cytochrome P450 reductase (Gorsky et al., 1984; Ekström and Ingelman-Sundberg, 1989). The latter feature of cytochrome P4502E1 involves a high NADPH oxidase activity, with enhanced production of $\mathrm{O}_{2}{ }^{-}$and hydrogen peroxide $\left(\mathrm{H}_{2} \mathrm{O}_{2}\right)$ during microsomal NADPH oxidation, and represents an effective catalyst for lipid peroxidation (Ekström and Ingelman-Sundberg, 1989; Dai et al., 1993). In view of these considerations, the aim of this study was to evaluate the influence of $\mathrm{HCCH}$ treatment on liver microsomal $\mathrm{O}_{2}$ production in relation to cytochrome P4502E1-dependent activity and content of this specific isoenzyme. To achieve this aim, liver microsomal hydroxylation of $\mathrm{p}$ nitrophenol (PNP)(Reinke and Moyer, 1985) and immunoblot analysis (Towbin et al., 1979) were performed in control and $\mathrm{HCCH}$ - treated rats, and results were compared to values found in animals after L-3,3',5triiodothyronine $\left(\mathrm{T}_{3}\right)$ administration, which is known to induce oxidative stress in the liver involving enhanced microsomal $\mathrm{O}_{2}$. generation (Fernández et al., 1985; Massa and Fernández., 1999).

\section{MATERIALS AND METHODS}

\section{Animals and treatments}

Male Sprague-Dawley rats weighing 200$250 \mathrm{~g}$ were given free access to food and water and maintained on a $12 \mathrm{~h}$ light/dark cycle. Animals received a single i.p. injection of $40 \mathrm{mg} \mathrm{HCCH} / \mathrm{kg}$ body weight or equivalent volumes of corn oil $(\mathrm{HCCH}$ diluent, controls). A separate group of rats were given daily i.p. doses of $0.1 \mathrm{mg} \mathrm{T}_{3} / \mathrm{kg}$ body weight for two consecutive days or equivalent volumes of $0.1 \mathrm{~N} \mathrm{NaOH}\left(\mathrm{T}_{3}\right.$ diluent, controls). Determinations were performed $24 \mathrm{~h}$ after $\mathrm{HCCH}$ or $\mathrm{T}_{3}$ treatment, time at which the hepatic content of $\mathrm{HCCH}$ was assayed by a gas chromatography technique (Bainy et al., 1993), the levels of $\mathrm{T}_{3}$ in serum were measured by radioimmunoassay (GammaCoat ${ }^{\mathrm{TM}}\left[{ }^{125} \mathrm{I}\right] \mathrm{T}_{3}$ Kit, Baxter Healthcare Corp., Cambridge, MA), and the thermogenic status of the animals was assessed by measurements of their rectal temperature (Fernández et al., 1985). All animals used received humane care according to the guidelines outlined in the Guide for the Care and Use of Laboratory Animals by the National Academy of Sciences (National Institutes of Health publication No. 86-23).

\section{Biochemical parameters}

Livers were homogenized in $150 \mathrm{mM} \mathrm{KCl}$ containing $5 \mathrm{mM}$ Tris, pH 7.4. Microsomal fractions were prepared by ultracentrifugation and washed once before suspension in $120 \mathrm{mM}$ potassium phosphate buffer, pH 7.2. These samples were used for the determination of the total content of cytochrome P450 (Omura and Sato, 1964), the production of $\mathrm{O}_{2}^{--}$by determining the 
superoxide dismutase-sensitive rate of adrenochrome formation at $485 \mathrm{~nm}$ (Boveris et al., 1983), and the activity of NADPHcytochrome $\mathrm{P} 450$ reductase by monitoring the reduction of cytochrome c at $550 \mathrm{~nm}$ (Williams and Kamin, 1962). Postmicrosomal cytosolic fractions were used to determine superoxide dismutase (SOD) activity (Misra and Fridovich, 1969).

Oxidation of PNP is a suitable assay for the determination of the microsomal activity dependent on cytochrome P4502E1 (Reinke and Moyer, 1985; Lieber, 1997). This was assayed by measuring the $\mathrm{A}_{546}$ of the 4-nitrocathecol produced, and activity was calculated using the extinction coefficient of $10.28 \mathrm{mM}^{-1} \mathrm{~cm}^{-1}$ (Reinke and Moyer, 1985). For Western immunoblotting, the proteins were separated by sodium dodecyl sulfate polyacrylamide gel electrophoresis (SDS-PAGE) according to Laemmli (1970). Proteins separated were electrotransferred to a nitrocellulose membrane as described by Towbin et al. (1979), with the Trans-Blot Cell system (Bio-Rad, Hercules, CA) in transfer buffer. The membranes were incubated with primary anti-rat cytochrome P4502E1 antibody (dilution 1:500), using acetone treated rat liver microsomes containing cytochrome P4502E1 (0.1 $\mu \mathrm{g} / \mathrm{blot})$ as a standard (Daiichi Pure Chemicals Co. Ltd., Tokyo, Japan). This was followed by incubation with anti-rat IgG antibody coupled to horseradish peroxidase (dilution 1:5000) (Jackson ImmunoResearch Laboratories Inc., West Grove, PA) and subsequent detection of luminol reactive bands with 4-chloro-1-naphtol and hydrogen peroxide. The protein content of microsomal and cytosolic fractions was determined according to Lowry et al. (1951).

\section{Statistical analysis}

Values shown correspond to the means \pm SEM for the number of separate experiments indicated. The statistical significance of differences among multiple groups was carried out by one-way ANOVA followed by the Newman-Keuls' test, and is indicated by the letters identifying each experimental group.

\section{RESULTS AND DISCUSSION}

Administration of $\mathrm{HCCH}$ to rats resulted in a higher content of the insecticide in the liver compared with that in control animals [controls, not detectable $(n=4)$; $\mathrm{HCCH}-$ treated rats, $5.81 \pm 1.14 \mu \mathrm{g} / \mathrm{g}$ wet liver $(\mathrm{n}=5)]$. In these conditions, HCCH led to a $43 \%$ increase $(p<0.05)$ in the content of total cytochrome $\mathrm{P} 450$ of the liver (Fig. 1A), in agreement with earlier reports (Srinivasan and Radhakrishnamurty, 1983; Junqueira et al., 1988).

\section{A. Cytochrome P450 content}

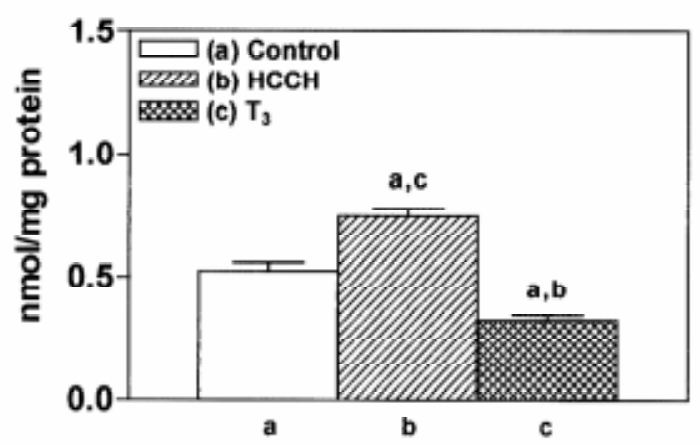

B. NADPH-cytochrome P450 reductase activity

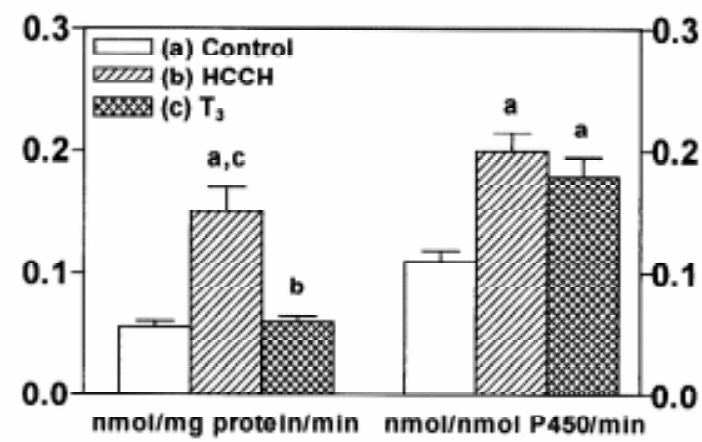

Figure 1. Content of cytochrome P450 (A) and NADPHcytochrome $\mathrm{P} 450$ reductase activity (B) in liver microsomal fractions of control rats and animals subjected to $\gamma$ hexachlorocyclohexane (HCCH) or L-3, 3', 5-triiodothyronine $\left(\mathrm{T}_{3}\right)$ administration. Control rats for $\mathrm{HCCH}$ and $\mathrm{T}_{3}$ treatments exhibited comparable values ( $p>0.05$ ) and constitute a single group. Values shown correspond to means \pm SE for 7-15 animals per experimental group. The significance of the differences between mean values $(\mathrm{P}<0.05)$ was assessed by one-way ANOVA and the Newman-Keuls test, and it is shown by the letters identifying each experimental group. 
Concomitantly, the specific activity of hepatic NADPH-cytochrome P450 reductase is enhanced by $171 \%$ following $\mathrm{HCCH}$ administration, over control values, with a $90 \%$ increase being found when expressed in terms of cytochrome P450 content (molecular activity) (Fig. 1B). $\mathrm{T}_{3}$ administration, involving higher levels of the hormone in serum [controls, $48 \pm 5 \mathrm{ng}$ / dl $(n=5) ; T_{3}$-treated rats, $277 \pm 35(n=5)$; $\mathrm{p}<0.05]$ and enhanced rectal temperature of the animals [controls, $36.9 \pm 0.02{ }^{\circ} \mathrm{C}$ $(\mathrm{n}=5) ; \mathrm{T}_{3}$-treated rats, $38.2 \pm 0.02(\mathrm{n}=12)$; $\mathrm{p}<0.05$ ], elicited a $37 \%$ decrease $(\mathrm{p}<0.05)$ in the cytochrome $\mathrm{P} 450$ content of the liver (Fig. 1A). Although $\mathrm{T}_{3}$ administration for two consecutive days failed to modify the specific activity of NADPH-cytochrome $\mathrm{P} 450$ reductase (Fig. 1B), which is enhanced after $\mathrm{T}_{3}$ treatment for three consecutive days (Simon-Giavarotti et al., 1998), the molecular activity of the enzyme is elevated by $69 \%$ (Fig. 1B). HCCH- and $\mathrm{T}_{3}$-induced changes in total cytochrome $\mathrm{P} 450$ content and NADPH-cytochrome $\mathrm{P} 450$ reductase activity were paralleled by a significant increase in the microsomal NADPHdependent $\mathrm{O}_{2}$-- generation, expressed either per $\mathrm{mg}$ of protein (92 and 53\%, respectively) or per nmol of cytochrome P450 (35 and $150 \%$, respectively) (Fig. 2A). Considering that $\mathrm{HCCH}$ and $\mathrm{T}_{3}$ elicited a 17 and $37 \%$ reduction in the activity of cytosolic SOD (Fig. 2B), the respective $\mathrm{O}_{2}-$ generation/ SOD activity ratios were enhanced by $135 \%$ over control values (Fig. 2C). This unbalance in the $\mathrm{O}$ - production/utilization equilibrium by $\mathrm{HCCH}$ or $\mathrm{T}_{3}$ treatment indicates a major derangement in the disposition of the free radical, that may contribute to the enhancement in the oxidative stress status of the liver (Videla et al., 1990; Videla, 2000). The above findings, and the observation that the activity of the NADPH-generating enzyme glucose-6-phosphate dehydrogenase is not altered by $\mathrm{HCCH}$ (Junqueira et al., 1986) or increased by $\mathrm{T}_{3}$ (Simon-Giavarotti et al., 1998), may imply greater rates of cytochrome $\mathrm{P} 450$ reduction and, consequently, of $\mathrm{O}_{2}^{--}$production in both experimental conditions (Fig. 2A). This suggestion is supported by the significant enhancement elicited by $\mathrm{HCCH}$ and $\mathrm{T}_{3}$ administration upon liver microsomal NADPH-dependent $\mathrm{O}_{2}$ consumption

\section{A. Superoxide radical production}

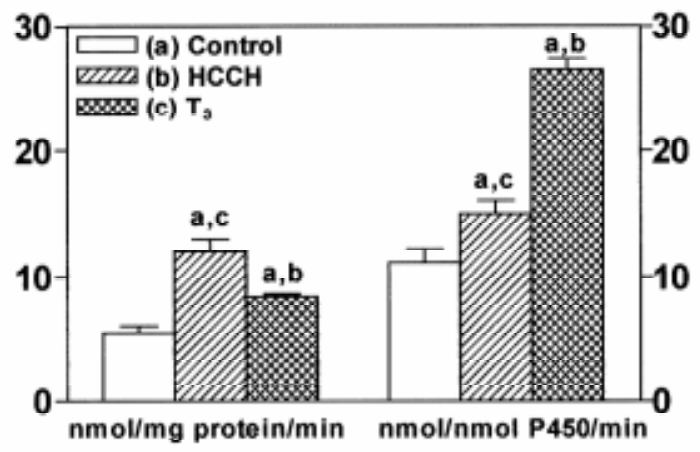

B. SOD activity

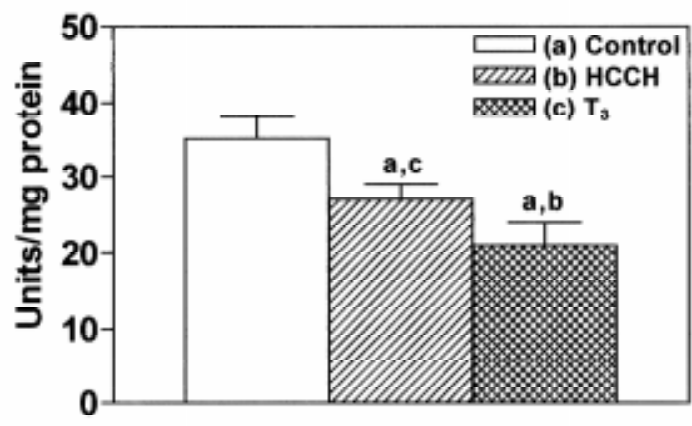

C. $\mathrm{O}_{2} \cdot \% \mathrm{SOD}$ ratio

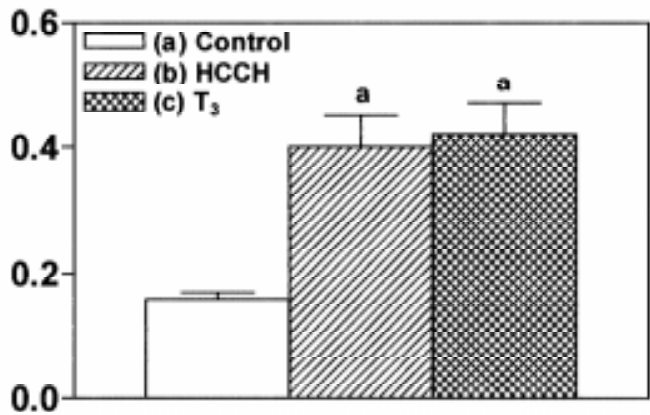

Figure 2. Microsomal NADPH-dependent superoxide radical $\left(\mathrm{O}_{2}^{-}\right)$production $(\mathrm{A})$, superoxide dismutase (SOD) activity (B), and $\mathrm{O}_{2}$ production/SOD activity ratios (C) in the liver of control rats and animals subjected to $\gamma$-hexachlorocyclohexane $(\mathrm{HCCH})$ or L-3,3',5-triiodothyronine $\left(\mathrm{T}_{3}\right)$ administration. Control rats for $\mathrm{HCCH}$ and $\mathrm{T}_{3}$ treatments exhibited comparable values ( $p>0.05)$ and constitute a single group. Values shown correspond to means \pm SE for 7-13 animals per experimental group. The significance of the differences between mean values $(\mathrm{P}<0.05)$ was assessed by one-way ANOVA and the Newman-Keuls' test, and it is shown by the letters identifying each experimental group. 
(Videla et al., 1988; Fernández et al., 1988), which is largely inhibited by the free radical scavenger cyanidadol, and in NADPH oxidase activity (Fernández et al., 1985; Junqueira et al., 1994). In addition to these changes, $\mathrm{HCCH}$ and $\mathrm{T}_{3}$ also induce liver microsomal chemiluminescence, a response related to the formation of electronically excited species in oxidative radical reactions (Fernández et al., 1985; Junqueira et al. 1988), thus indicating an overall prooxidant condition at the microsomal level.
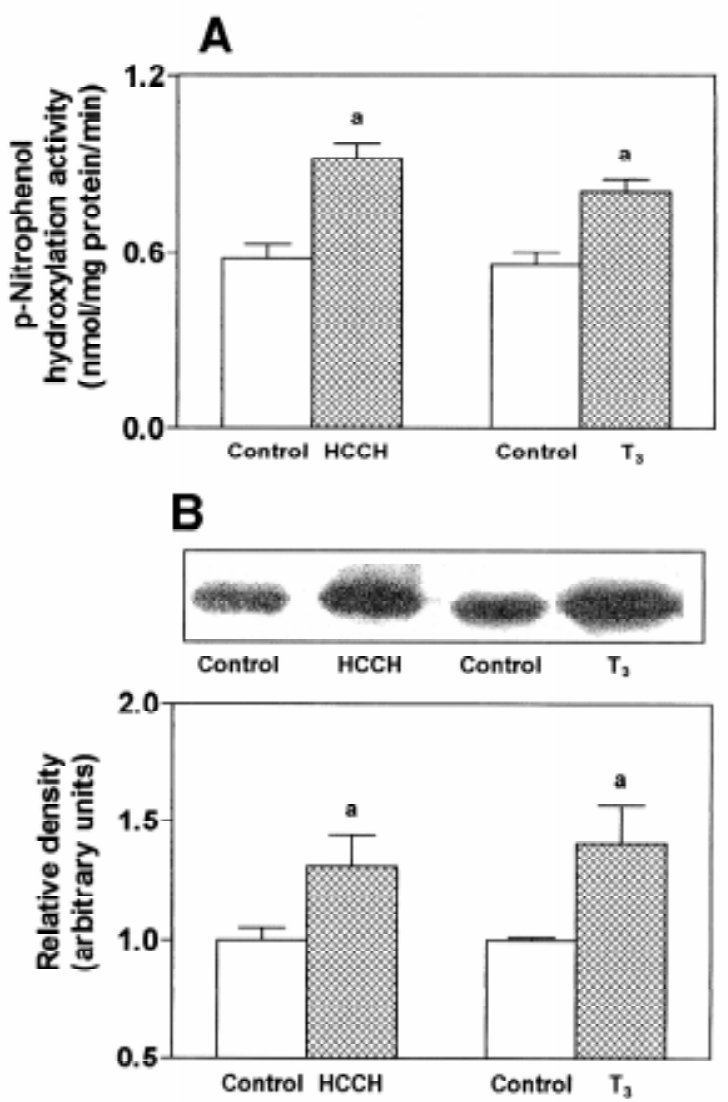

Figure 3. Microsomal activity of p-nitrophenol hydroxylation (A) and western blot analysis of cytochrome P4502E1 (B) in the liver of control rats and animals subjected to $\gamma$ hexachlorocyclohexane (HCCH) or L-3,3',5-triiodothyronine $\left(\mathrm{T}_{3}\right)$ administration. Representative blots shown in the upper panel in B contain $30 \mu \mathrm{g}$ of microsomal protein from a different rat per lane. Data on the lower panel in B show the densitometric analysis of the immunoblots presented in the upper panel; for this purpose, data from both groups of control rats were set to unity, and values from $\mathrm{HCCH}$ - and $\mathrm{T}_{3}$-treated rats were normalized to respective control group. Values shown correspond to means \pm SE for 4-10 animals per group in $\mathrm{A}$ and 3 rats per group in $\mathrm{B}$. The significance of the differences between mean values $(\mathrm{P}<0.05)$ was assessed by one-way ANOVA and the Newman-Keuls test, and it is shown by the letters identifying each experimental group.
Assessment of the rate of hydroxylation of PNP by liver microsomes showed increases of 58 and $45 \%$ in $\mathrm{HCCH}-$ and $\mathrm{T}_{3}-$ treated rats, respectively (Fig. 3A), with the parallel induction of cytochrome P4502E1 (Fig. 3B). The significant 31\% $(\mathrm{HCCH})$ and $41 \%\left(\mathrm{~T}_{3}\right)$ increases in the content of cytochrome P4502E1 support the latter finding, assessed by western immunoblotting (Fig. 3B). Considering that microsomal PNP hydroxylation depends on the content of cytochrome P4502E1 (Reinke and Moyer, 1985; Koop, 1986), these results suggest the possibility that induction of cytochrome P4502E1 by $\mathrm{HCCH}$ and $\mathrm{T}_{3}$ may play a role in the increased production of $\mathrm{O}_{2}{ }^{-}$. This hypothesis is supported by the substantial NADPH oxidase activity exhibited by cytochrome P4502E1 when reduced by NADPH-cytochrome $\mathrm{P} 450$ reductase (Gorsky et al., 1984; Ingelman-Sundberg and Johanson, 1984), and by the significant correlation established between microsomal $\mathrm{O}_{2}$-- generation and PNP hydroxylation $(\mathrm{r}=$ $0.96 ; \mathrm{p}<0.01)$ or cytochrome P4502E1 content $(r=0.68 ; p<0.05)$. In agreement with these findings, induction of cytochrome P4502E1 exhibits a significant correlation with lipid peroxidation, production of reactive $\mathrm{O}_{2}$ species, formation of 1-hydroxylethyl radical from ethanol, and liver injury after prolonged ethanol feeding (Ekström and Ingelman-Sundberg, 1989; Reinke et al., 1990). In humans, cytochrome P4502E1 induction has been proposed to play a key role in the production of cellular injury in alcoholic hepatitis (Takahashi et al., 1993), a feature observed also in patients with nonalcoholic fatty liver disease (Weltman et al., 1998). Furthermore, significant cytotoxicity is observed in a transfected HepG2 cell line expressing human cytochrome P4502E1 when exposed to acetaminophen or ethanol (Dai and Cederbaum, 1995; Wu and Cederbaum, 1996).

Collectively, data presented indicate that $\mathrm{HCCH}$ and $\mathrm{T}_{3}$ enhance the expression and activity of cytochrome $\mathrm{P} 4502 \mathrm{E} 1$ in rat liver. These effects occur regardless of the changes in total cytochrome P450 content, involve a substantial increase in the 
molecular activity of NADPH-cytochrome $\mathrm{P} 450$ reductase of liver microsomes, and may represent contributory mechanisms for NADPH-dependent $\mathrm{O}_{2}^{--}$generation and related hepatotoxicity (Videla et al., 1990; Videla, 2000). The latter view is in line with the finding that enhanced susceptibility of the liver to the toxic effects of acute lindane treatment in hyperthyroid state is produced by potentiation of the hepatic oxidative stress status (Videla et al., 1995; Simon-Giavarotti et al., 1998). This effect involves increases in the molecular activity of NADPH-cytochrome $\mathrm{P} 450$ reductase and in the $\mathrm{O}_{2}^{-}-\mathrm{SOD}$ ratio, and reduction of hepatic $\alpha$-tocopherol and GSH contents, in a magnitude exceeding the sum of effects elicited by the separate treatments (Videla et al., 1995; Simon-Giavarotti et al., 1998).

\section{ACKNOWLEDGMENTS}

This work was supported by grants 1030499 from FONDECYT (Chile) and 97/02335-5 from FAPESP and 301420/79-3 from CNPq (Brasil). The authors thank Dr. Patricia Varela and Pamela Cornejo for helpful discussions.

\section{REFERENCES}

BAINY ACD, ARISI ACM, AZZALIS LA, SIMIZU K, BARROS SBM, VIDELA LA, JUNQUEIRA VBC (1993) Differential effects of short-term lindane administration on parameters related to oxidative stress in rat liver and erythrocytes. J Biochem Toxicol 8: $187-194$

BAKER MT, NELSON RM, VAN DYKE RA (1985) The formation of chlorobenzene and benzene by the reductive metabolism of lindane in rat liver microsomes. Arch Biochem Biophys 236:506-514

BARROS SBM, VIDELA LA, SIMIZU K, VAN HALSEMA L, JUNQUEIRA VBC (1988) Lindaneinduced oxidative stress. II. Time course of changes in hepatic glutathione status. Xenobiotica 18:13051310

BOVERIS A, FRAGA CG, VARSAVSKY AI, KOCH OR (1983) Increased chemiluminescence and superoxide production in the liver of chronically ethanol-treated rats. Arch Biochem Biophys 227:534-538

COMPORTI M (1989) Three models of free radicalmediated cell injury. Chem Biol Interactions 72:1-56

DAI Y, RASHBA-STEP J, CEDERBAUM AI (1993) Stable expression of human cytochrome P-4502E1 in HepG2 cells: Characterization of catalytic activities and production of reactive oxygen intermediates. Biochemistry 32:6928-6937
DAI Y, CEDERBAUM AI (1995) Cytotoxicity of acetaminophen in human cytochrome P4502E1transfected HepG2 cells. J Pharmacol Exp Ther 273:1497-1505

EKSTRÖM G, INGELMAN-SUNDBERG M (1989) Rat liver microsomal NADPH supported oxidase activity and lipid peroxidation dependent on ethanol-inducible cytochrome P-450 (P-450IIE1). Biochem Pharmacol 38:1313-1319

FERNÁNDEZ V, BARRIENTOS X, KIPREOS K, VALENZUELA A, VIDELA LA (1985) Superoxide radical generation, NADPH oxidase activity, and cytochrome P-450 content of rat liver microsomal fractions in an experimental hyperthyroid state: relation to lipid peroxidation. Endocrinology 117:496501

FERNÁNDEZ V, LLESUY S, SOLARI L, KIPREOS K, VIDELA LA, BOVERIS A (1988) Chemiluminescent and respiratory responses related to thyroid hormoneinduced liver oxidative stress. Free Rad Res Commun $5: 77-84$

FERNÁNDEZ V, VIDELA LA (1996) Biochemical aspects of cellular antioxidant systems. Biol Res 29:177-182

FERNÁNDEZ V, CORNEJO P, VIDELA LA (1999) Influence of an iron overload and its interaction with hyperthyroidism and lindane intoxication on liver nitric oxide generation. Biol Res 32:R-187

GUENGERICH FP, KIM DH, IWASAKI M (1991) Role of human cytochrome P-450 IIE1 in the oxidation of many low molecular weight cancer suspects. Chem Res Toxicol 4:168-179

GORSKY LD, KOOP DR, COON MJ (1984) On the stoichiometry of the oxidase and monooxygenase reactions catalyzed by liver microsomal cytochrome P-450. J Biol Chem 259:6812-6817

INGELMAN-SUNDBERG M, JOHANSON I (1984) Mechanisms of hydroxyl radical formation and ethanol oxidation by ethanol inducible and other forms of rabbit liver microsomal cytochromes P-450. J Biol Chem 259:6447-6458

JUNQUEIRA VBC, SIMIZU K, VIDELA LA, BARROS SBM (1986) Dose-dependent study of the effects of acute lindane administration on rat liver superoxide anion production, antioxidant enzyme activities, and lipid peroxidation. Toxicology 41:193-204

JUNQUEIRA VBC, SIMIZU K, VAN HALSEMA L, KOCH OR, BARROS SBM, VIDELA LA (1988) Lindane-induced liver oxidative stress. I. Antioxidant enzymes, lipid peroxidation indexes, and morphologic characteristics. Xenobiotica 18:1297-1304

JUNQUEIRA VBC, BAINY ACD, ARISI ACM, AZZALIS LA, SIMIZU K, PIMENTEL R, BARROS SBM, VIDELA LA (1994) Acute lindane intoxication: a study on lindane tissue concentration and oxidative stress-related parameters in liver and erythrocytes. J Biochem Toxicol 9:9-15

JUNQUEIRA VBC, KOCH OR, ARISI ACM, FUZARO AP, AZZALIS LA, BARROS SBM, CRAVERO A, FARRÉ S, VIDELA LA (1997) Regression of morphological alterations and oxidative stress-related parameters after acute lindane-induced hepatotoxicity in rats. Toxicology 117:199-205

KAPPUS H (1987) Oxidative stress in chemical toxicity. Arch Toxicol 60:144-149

KOOP DR (1986) Hydroxylation of p-nitrophenol by rabbit ethanol inducible cytochrome P-450 isozyme $3 \mathrm{a}$. Mol Pharmacol 29:399-404 
KOOP DR (1992) Oxidative and reductive metabolism by cytochrome P-450 2E1. FASEB J 6:724-730

KURIHARA N, TANAKA K, NAKAJIMA M (1979) Mercapturic acid formation from lindane in rats. Pest Biochem Physiol 10:137-150

LAEMMLI UK (1970) Cleavage of structural proteins during the assembly of the head of bacteriophage $\mathrm{T}_{4}$. Nature 227:680-685

LIEBER CS (1997) Cytochrome P-4502E1: its physiological and pathological role. Physiol Rev 77:517-544

LOWRY OH, ROSEBROUGH NJ, FARR AL, RANDALL RJ (1951) Protein measurement with the Folin phenol reagent. J Biol Chem 193:265-275

MASSA L, FERNÁNDEZ V (1999) Hepatic microsomal activity in hyperthyroid rats with acute iron overload. Biol Res 32:R-187

MISRA HP, FRIDOVICH I (1969) The role of superoxide anion in the autoxidation of epinephrine and a simple assay for superoxide dismutase. J Biol Chem 247:3170-3175

OMURA T, SATO R (1964) The carbon-monoxide pigment of liver microsomes. I. Evidence for its hemoprotein nature. J Biol Chem 239:2370-2378

REINKE LA, MOYER MJ (1985) p-Nitrophenol hydroxylation. A microsomal oxidation which is highly inducible by ethanol. Drug Met Disp 13:548552

REINKE LA, LAU EK, DUBOSE CM, MCCAY PB (1990) Reactive free radical generation in vivo in heart and liver of ethanol-fed rats: correlation with radical formation in vitro. Proc Natl Acad Sci USA 87:54995503

SIMON-GIAVAROTTI KA, RODRIGUES L, RODRIGUES T, JUNQUEIRA VBC, VIDELA LA (1998) Liver microsomal parameters related to oxidative stress and antioxidant systems in hyperthyroid rats subjected to acute lindane treatment. Free Rad Res 29:35-42
SRINIVASAN F, RADHAKRISHNAMURTY R (1983) Induction of liver mixed function oxygenase system by $\beta$ - and $\gamma$-hexachlorocyclohexane. Indian J Biochem Biophys 20:84-91

TAKAHASHI T, LASKER JM, ROSMAN AS, LIEBER CS (1993) Induction of cytochrome P-4502E1 in the human liver by ethanol is caused by a corresponding increase in encoding messenger RNA. Hepatology 17:236-245

TOWBIN H, STAEHELIN T, GORDON J (1979) Electrophoretic transfer of proteins from polyacrylamide gels to nitrocellulose sheets: procedure and some applications. Proc Natl Acad Sci USA 76:4350-4354

VIDELA LA, BARROS SBM, SIMIZU K, JUNQUEIRA VBC (1988) Liver and biliary levels of glutathione and thiobarbituric acid reactants after acute lindane administration. Cell Biochem Funct 6:47-52

VIDELA LA, BARROS SBM, JUNQUEIRA VBC (1990) Lindane-induced liver oxidative stress. Free Rad Biol Med 9:169-179

VIDELA LA, SMOK G, TRONCOSO P, SIMON KA, JUNQUEIRA VBC, FERNÁNDEZ V (1995) Influence of hyperthyroidism on lindane-induced hepatotoxicity in the rat. Biochem Pharmacol 50:1557-1565

VIDELA LA (2000) Energy metabolism, thyroid calorigenesis, and oxidative stress: functional and cytotoxic consequences. Redox Report 5:265-275

WELTMAN MD, FARRELL GC, HALL P, INGELMANSUNDBERG M, LIDDLE C (1998) Hepatic cytochrome P450 2E1 is increased in patients with nonalcoholic steatohepatitis. Hepatology 27:128-133

WILLIAMS L, KAMIN H (1962) Microsomal triphosphopyridine nucleotide-cytochrome c reductase of liver. J Biol Chem 237:587-595

WU D, CEDERBAUM AI (1996) Ethanol cytotoxicity to a transfected HepG2 cell line expressing human cytochrome P4502E1. J Biol Chem 271:23914-23919 